\title{
Sulfurihydrogenibium azorense, sp. nov., a thermophilic hydrogen-oxidizing microaerophile from terrestrial hot springs in the Azores
}

\author{
Correspondence \\ A.-L. Reysenbach \\ reysenbacha@pdx.edu
}

\author{
P. Aguiar, ${ }^{1}$ T. J. Beveridge ${ }^{2}$ and A.-L. Reysenbach ${ }^{1}$ \\ ${ }^{1}$ Portland State University, Department of Biology, Portland, OR 97201, USA \\ ${ }^{2}$ Department of Microbiology, College of Biological Science, University of Guelph, Guelph, \\ Ontario, Canada N1G 2W1
}

Five hydrogen-oxidizing, thermophilic, strictly chemolithoautotrophic, microaerophilic strains, with similar (99-100\%) 16S rRNA gene sequences were isolated from terrestrial hot springs at Furnas, São Miguel Island, Azores, Portugal. The strain, designated Az-Fu1 ${ }^{\top}$, was characterized. The motile, 0.9-2.0 $\mu \mathrm{m}$ rods were Gram-negative and non-sporulating. The temperature growth range was from 50 to $73^{\circ} \mathrm{C}$ (optimum at $68^{\circ} \mathrm{C}$ ). The strains grew fastest in $0.1 \%(w / v) ~ N a C l$ and at $\mathrm{pH} 6$, although growth was observed from $\mathrm{pH} 5 \cdot 5$ to $7 \cdot 0 . \mathrm{Az}-\mathrm{Fu} 1^{\top}$ can use elemental sulfur, sulfite, thiosulfate, ferrous iron or hydrogen as electron donors, and oxygen $(0 \cdot 2-9 \cdot 0 \%, \mathrm{v} / \mathrm{v})$ as electron acceptor. $\mathrm{Az}-\mathrm{Fu} 1^{\top}$ is also able to grow anaerobically, with elemental sulfur, arsenate and ferric iron as electron acceptors. The Az-Fu1 ${ }^{\top} \mathrm{G}+\mathrm{C}$ content was $33.6 \mathrm{~mol} \%$. Maximum-likelihood analysis of the 16S rRNA phylogeny placed the isolate in a distinct lineage within the Aquificales, closely related to Sulfurihydrogenibium subterraneum (2.0\% distant). The $16 \mathrm{~S}$ rRNA gene of $\mathrm{Az}-\mathrm{Fu} 1^{\top}$ is $7 \cdot 7 \%$ different from that of Persephonella marina and $6 \cdot 8 \%$ different from Hydrogenothermus marinus. Based on the phenotypic and phylogenetic characteristics presented here, it is proposed that $\mathrm{Az}-\mathrm{Fu} 1^{\top}$ belongs to the recently described genus Sulfurihydrogenibium. It is further proposed that $\mathrm{Az}-\mathrm{Fu} 1^{\top}$ represents a new species, Sulfurihydrogenibium azorense.
Based on phylogenetic analysis of the small-subunit rRNA (16S rRNA) gene sequences, the order Aquificales is the deepest lineage within the domain Bacteria (Burggraf et al., 1992; Pitulle et al., 1994). All members of the Aquificales, with the exception of 'Hydrogenobacter subterraneus', are chemolithoautotrophic, microaerophilic, thermophilic to hyperthermophilic, hydrogen-oxidizing ('Knallgas') bacteria (Aragno, 1992). Currently, the order Aquificales harbours seven genera: Aquifex (Huber et al., 1992), Hydrogenobacter (Saveleva et al., 1982; Kawasumi et al., 1984; Stöhr et al., 2001), Hydrogenobaculum (Shima \& Suzuki, 1993; Stöhr et al., 2001), Thermocrinis (Huber et al., 1998; Eder \& Huber, 2002), Hydrogenothermus (Stöhr et al., 2001), Persephonella (Götz et al., 2002) and the recently described Sulfurihydrogenibium (Takai et al., 2003). Members of the order are widespread in both terrestrial and deepsea hydrothermal systems and have been isolated from shallow marine (Huber et al., 1992; Nishihara et al., 1990; Stöhr et al., 2001) and terrestrial hydrothermal systems (Kryukov et al., 1983; Kawasumi et al., 1984; Shima \& Suzuki, 1993; Huber et al., 1998; Kristjansson et al., 1985),

The GenBank accession number for the $16 \mathrm{~S}$ rRNA sequence of strain $\mathrm{Az}-\mathrm{Fu} 1^{\top}$ is AF528192. from heated compost (Beffa et al., 1996), from deep-sea hydrothermal vents (Reysenbach et al., 2000a) and recently from a subsurface gold mine (Takai et al., 2002, 2003).

Using molecular phylogenetic techniques it has been shown that near neutral terrestrial thermal springs (above $65^{\circ} \mathrm{C}$ ) are often dominated by members of the Aquificales (Yamamoto et al., 1998; Reysenbach et al., 2000b; Skirnisdottir et al., 2000) and referred to as 'black filaments' (Reysenbach et al., 2000b) or 'sulfur-turf' (Yamamoto et al., 1998; Hjörleifsdottir et al., 2001) due to their tendency to form extensive microbial mats that appear black or yellow from iron or sulfur mineral deposits. Using a combination of culture-dependent techniques and molecular analyses, we isolated the first terrestrial representative of these Aquificales from a terrestrial hot spring in the Azores, Portugal (Reysenbach et al., 2002a), and we propose a new species, Sulfurihydrogenibium azorense sp. nov.

Water and filamentous biomass samples were collected in Bellco serum bottles (Bellco Glass) in the area of Água do Caldeirão, Furnas, on São Miguel Island, Azores, in January of 2001. The temperature measured at the sampling sites varied between 65 and $70{ }^{\circ} \mathrm{C}$ and the $\mathrm{pH}$ varied between 5.9 and $7 \cdot 0$. A sample $(0.5 \mathrm{ml})$ was inoculated into $5 \mathrm{ml}$ 
modified MSH medium with a final gas phase of $\mathrm{CO}_{2} / \mathrm{O}_{2} /$ $\mathrm{H}_{2}(41 \cdot 6: 1 \cdot 8: 56 \cdot 6$, by vol., $242 \cdot 5 \mathrm{kPa})$. Modified $\mathrm{MSH}$ medium (Boone et al., 1989) was prepared with anoxic distilled water under a $\mathrm{CO}_{2}$ atmosphere and contained $\left(\mathrm{l}^{-1}\right): 2 \mathrm{~g} \mathrm{NaOH}, 0.5 \mathrm{~g} \mathrm{KCl}, 1.36 \mathrm{~g} \mathrm{MgCl}_{2} .6 \mathrm{H}_{2} \mathrm{O}, 7 \mathrm{~g}$ $\mathrm{MgSO}_{4} .7 \mathrm{H}_{2} \mathrm{O}, 2 \mathrm{~g} \quad \mathrm{Na}_{2} \mathrm{~S}_{2} \mathrm{O}_{3} .5 \mathrm{H}_{2} \mathrm{O}, 0.4 \mathrm{~g} \quad \mathrm{CaCl}_{2} .2 \mathrm{H}_{2} \mathrm{O}$, $0.2 \mathrm{~g} \mathrm{NH}_{4} \mathrm{Cl}, 0.3 \mathrm{~g} \mathrm{~K}_{2} \mathrm{HPO}_{4} .3 \mathrm{H}_{2} \mathrm{O}$ and $10 \mathrm{ml}$ of a trace element stock solution (adapted from Ferguson \& Mah, 1983). Prior to autoclaving, the $\mathrm{pH}$ of the medium was adjusted to 6.0 with $10 \mathrm{M} \mathrm{NaOH} . \mathrm{O}_{2}$ was added after autoclaving and the tubes were pressurized with $\mathrm{H}_{2}$ after inoculation.

Enrichments were incubated for 1 day at $70^{\circ} \mathrm{C}$, without agitation, and immediately transferred. The cultures were purified by four consecutive end-point dilutions on modified MSH medium. Colonies were isolated on $2 \%(\mathrm{w} / \mathrm{v})$ gelrite roll tubes (Jones et al., 1983). The gelrite medium (iron-reducing or $\mathrm{H}_{2}$-oxidizing) was supplemented with $0.001 \%(\mathrm{w} / \mathrm{v}) \mathrm{CuSO}_{4} \cdot 5 \mathrm{H}_{2} \mathrm{O}$, according to Masaharu et al. (1987). Pure cultures were stored in modified MSH medium containing $15 \%(\mathrm{v} / \mathrm{v})$ glycerol both at $-80^{\circ} \mathrm{C}$ and in liquid nitrogen.

Growth was determined either by measuring changes in $\mathrm{OD}_{600}$, by total protein content (Coomassie protein assay) or by direct cell counts using a Petroff-Hauser counting chamber. Unless otherwise stated, all growth experiments were done at $68{ }^{\circ} \mathrm{C}$, under the microaerophilic conditions described above, and conducted in triplicate. Az-Fu1 ${ }^{\mathrm{T}}$ growth with and without agitation was compared. The effect of $\mathrm{pH}$ on growth was determined from $\mathrm{pH} 4.0$ to 8.5 using acetate/acetic acid buffer, MES, PIPES, HEPES and Tris/HCl. The $\mathrm{pH}$ of the medium was adjusted prior to autoclaving, checked after $1 \mathrm{~h}$ incubation at $68^{\circ} \mathrm{C}$ and checked again at the end of growth. $\mathrm{NaCl}$ requirements were determined at $0-4 \%(\mathrm{w} / \mathrm{v}) \mathrm{NaCl}$. Oxygen requirements and tolerance were determined by injecting defined volumes of pure $\mathrm{O}_{2}$ into culture tubes. $\mathrm{O}_{2}$ final concentrations from 0 to $12 \%(\mathrm{v} / \mathrm{v})$ were tested. The optimal temperature for growth was determined by calculating specific growth rates of cultures incubated at various temperatures. The relationship of specific growth rate to temperature was then fitted with TableCurve (2D Windows, v4.07; AISN Software) to the square-root equation Ratkowsky et al. (1982).

Electron acceptors and electron donors were added after autoclaving to a minimal medium (modified MSH medium without $\mathrm{Na}_{2} \mathrm{~S}_{2} \mathrm{O}_{3}$ and with only $4 \mathrm{~g} \mathrm{MgSO}_{4} .7 \mathrm{H}_{2} \mathrm{O} \mathrm{l}^{-1}$ to ensure an adequate sulfur source) (Table 1). Soluble (ferric citrate, $10 \mathrm{mM}$ ) and insoluble (ferrihydrite) iron (III) $(10 \mathrm{mM})$ was used. Ferrous iron was added at $10 \mathrm{mM}$, sulfur was added at $1 \%(\mathrm{w} / \mathrm{v})$ and $\mathrm{NH}_{4}^{+}$was tested at $10 \mathrm{mM}$ final concentration. $\mathrm{SeO}_{4}^{2-}, \mathrm{SeO}_{3}^{2-}, \mathrm{AsO}_{4}^{3-}$ and $\mathrm{AsO}_{3}^{3-}$ were added according to Takai et al. (2002) and all other electron donors and acceptors were at concentrations reported by Götz et al. (2002). Controls contained no electron acceptor and no electron donor. Abiotic controls
Table 1. Observed metabolic differences between strain $\mathrm{Az}-\mathrm{Fu} 1^{\top}$ and Sulfurihydrogenibium subterraneum

Both isolates could use $\mathrm{H}_{2}+\mathrm{O}_{2}, \mathrm{~S}^{\circ}+\mathrm{O}_{2}, \mathrm{~S}_{2} \mathrm{O}_{3}^{2-}+\mathrm{O}_{2}, \mathrm{~S}^{\circ}+\mathrm{Fe}^{3+}$ and $\mathrm{H}_{2}+\mathrm{Fe}^{3+}$, but could not grow with $\mathrm{O}_{2}+\mathrm{SeO}_{3}^{2-}$ or $\mathrm{H}_{2}+\mathrm{NO}_{2}^{-}$. Data for Sulfurihydrogenibium subterraneum are taken from Takai et al. (2003). ND, Not determined; -, no growth.

\begin{tabular}{|c|c|c|}
\hline Character & Az-Ful ${ }^{T}$ & $\begin{array}{c}\text { Sulfurihydrogenibium } \\
\text { subterraneum }\end{array}$ \\
\hline \multicolumn{3}{|l|}{ Iron metabolism } \\
\hline $\mathrm{S}_{2} \mathrm{O}_{3}^{2-}+\mathrm{Fe}^{3+}$ & $+^{*}$ & + \\
\hline $\mathrm{Fe}^{2+}+\mathrm{O}_{2}$ & $+^{*}$ & $+{ }^{*} \dagger$ \\
\hline $\mathrm{Fe}^{2+}+\mathrm{NO}_{3}^{-}$ & - & $\mathrm{ND}$ \\
\hline \multicolumn{3}{|l|}{ Nitrogen metabolism } \\
\hline $\mathrm{H}_{2} / \mathrm{S}^{\circ} / \mathrm{S}_{2} \mathrm{O}_{3}^{2-}+\mathrm{NO}_{3}^{-}$ & - & + \\
\hline $\mathrm{NH}_{4}^{+}+\mathrm{O}_{2}$ & - & ND \\
\hline $\mathrm{NH}_{4}^{+}+\mathrm{NO}_{2}^{-}$ & - & ND \\
\hline \multicolumn{3}{|l|}{ Sulfur metabolism } \\
\hline $\mathrm{H}_{2}+\mathrm{S}^{\circ}$ & $+^{*}$ & $+{ }^{*} \dagger$ \\
\hline $\mathrm{H}_{2}+\mathrm{S}_{2} \mathrm{O}_{3}^{2-} / \mathrm{SO}_{4}^{2-}$ & - & $\mathrm{ND}$ \\
\hline $\mathrm{H}_{2}+\mathrm{SO}_{3}^{2-}$ & $+^{*}$ & $\mathrm{ND}$ \\
\hline $\mathrm{SO}_{3}^{2-}+\mathrm{O}_{2}$ & $+^{*}$ & ND \\
\hline \multicolumn{3}{|l|}{ Arsenic metabolism } \\
\hline $\mathrm{H}_{2} / \mathrm{S}^{\circ} / \mathrm{S}_{2} \mathrm{O}_{3}^{2-}+\mathrm{AsO}_{4}^{3-}$ & $+^{*}$ & + \\
\hline $\mathrm{AsO}_{3}^{3-}+\mathrm{O}_{2}$ & + & $+{ }^{*} \dagger$ \\
\hline \multicolumn{3}{|l|}{ Selenium metabolism } \\
\hline $\mathrm{H}_{2} / \mathrm{S}^{\circ} / \mathrm{S}_{2} \mathrm{O}_{3}^{2-}+\mathrm{SeO}_{4}^{2-}$ & $+^{*}$ & + \\
\hline $\mathrm{H}_{2} / \mathrm{S}^{\circ}+\mathrm{SeO}_{3}^{2-}$ & $+^{*}$ & + \\
\hline $\mathrm{S}_{2} \mathrm{O}_{3}^{2-}+\mathrm{SeO}_{3}^{2-}$ & - & + \\
\hline
\end{tabular}

${ }^{\star}$ Low growth yields.

$\dagger$ Data determined in this study.

were also used when necessary to validate the tests. Additionally, growth of Sulfurihydrogenibium subterraneum under similar conditions was used as a control.

Organic carbon sources were tested in the presence and in the absence of oxygen. Hydrogen was used as electron donor; however, we also tested whether the isolate can grow fermentatively. Carbon sources were added at $0 \cdot 1$ and $1 \%$ $(\mathrm{w} / \mathrm{v})$ final concentration (yeast extract, sucrose, fructose, glucose, mannose, maltose, starch, formate, casamino acids, tartaric acid, peptone), $0 \cdot 1 \%(\mathrm{v} / \mathrm{v})$ final concentration (methanol, formaldehyde, formamide), or 1 and $10 \mathrm{mM}$ final concentration (lactate, formate, succinate, oxalate, sorbitol, citrate and proprionate). Cultures were transferred at least twice on the same substrate combination to ensure that growth was not due to substrate carry-over from the inoculum.

Gram staining was carried out using standard procedures. For electron microscopy, samples were shipped overnight to Department of Microbiology, College of Biological Science, University of Guelph, Canada, in $1 \%(\mathrm{v} / \mathrm{v})$ glutaraldehyde. The samples were treated as described by Götz 
et al. (2002) using standard glutaraldehyde/osmium tetroxide fixation and LR White embedding regimens for thin sectioning (Beveridge et al., 1994).

Genomic DNA was extracted according to Götz et al. (2002). For the determination of DNA base composition, DNA was extracted from $1 \mathrm{~g}$ wet wt of the culture cell pellet. The cells were disrupted with a French pressure cell and the DNA was purified on hydroxyapatite according to the procedure of Cashion et al. (1977). For the DNA base composition the genomic DNA was hydrolysed according to Mesbah et al. (1989). The resulting deoxyribonucleosides were analysed by HPLC. Ten microlitres of sample were loaded in an HPLC system with a SelectaPore $90 \mathrm{M}, \mathrm{C}_{18}, 5 \mu \mathrm{m}$ $(250 \times 4.6 \mathrm{~mm})$ analytical column and the run was performed at $45^{\circ} \mathrm{C}$, with a $0.3 \mathrm{M}\left(\mathrm{NH}_{4}\right) \mathrm{H}_{2} \mathrm{PO}_{4}$ /acetonitrile solvent, $40: 1(\mathrm{v} / \mathrm{v}), \mathrm{pH} 4 \cdot 4$, at $1 \cdot 3 \mathrm{ml} \mathrm{min}^{-1}$ (adapted from Tamaoka \& Komagata, 1984). The calibration was done using non-methylated $\lambda$ DNA (Sigma; G $+C$ content $49 \cdot 86 \mathrm{~mol} \%)$ and the $\mathrm{G}+\mathrm{C}$ content was calculated according to Mesbah et al. (1989).

The 16S rRNA genes were amplified by PCR from genomic DNA, purified and sequenced as described by Götz et al. (2002). Platinum Taq DNA polymerase high fidelity (Invitrogen) was used to confirm the sequence as two single mismatches were detected in the sequence. A total of $1447 \mathrm{nt}$ were sequenced. Sequence alignment and phylogenetic analyses were done as described previously (Götz et al., 2002) using 1379 homologous nucleotides. Due to using a subset of Aquificales sequences and based on sequence alignments and secondary structure comparisons, $1430 \mathrm{nt}$ were used to construct distance matrices by pairwise analysis with the Jukes \& Cantor (1969) correction.

The new isolate $\mathrm{Az}-\mathrm{Fu} 1^{\mathrm{T}}$ is a thermophilic chemolithoautotrophic 'Knallgas' bacterium isolated from the Furnas hot springs, São Miguel, Azores. Light brown-white filamentous clumps appeared in the liquid medium after $24 \mathrm{~h}$ incubation. Based on initial 16S rRNA gene sequence all the isolates (five cultures) were 100-99\% similar in sequence and the isolate designated strain $\mathrm{Az}-\mathrm{Fu} 1^{\mathrm{T}}$ (previously designated Fc8A70; Reysenbach et al., 2002a) was chosen for further study, although optimal growth conditions were confirmed for all strains. Translucent colonies were obtained from gelrite roll tubes under iron-reducing and $\mathrm{H}_{2}$-oxidizing conditions. Successful transfer of the strains required a 5-10\% mid-exponential-growth-phase inoculum.

The isolate is phylogenetically most closely related to the uncultivated Aquificales environmental $16 \mathrm{~S}$ rDNA sequence SRI-40 (Fig. 4) obtained from Icelandic hot springs (Skirnisdottir et al., 2000; 0.2\% phylogenetic distance), although its closest relative in culture is Sulfurihydrogenibium subterraneum (Takai et al., 2003; $2 \cdot 0 \%$ distance). Furthermore, the Az-Fu1 ${ }^{\mathrm{T}}$ 16S rDNA sequence is $3 \cdot 1 \%$ distant from its Yellowstone relative, strain YNP-SS1 (Reysenbach et al., 2002b) and only about $18 \%$ distant from Aquifex pyrophilus. Az-Fu1 ${ }^{\mathrm{T}}$ is also $7 \cdot 7$ and $6 \cdot 8 \%$

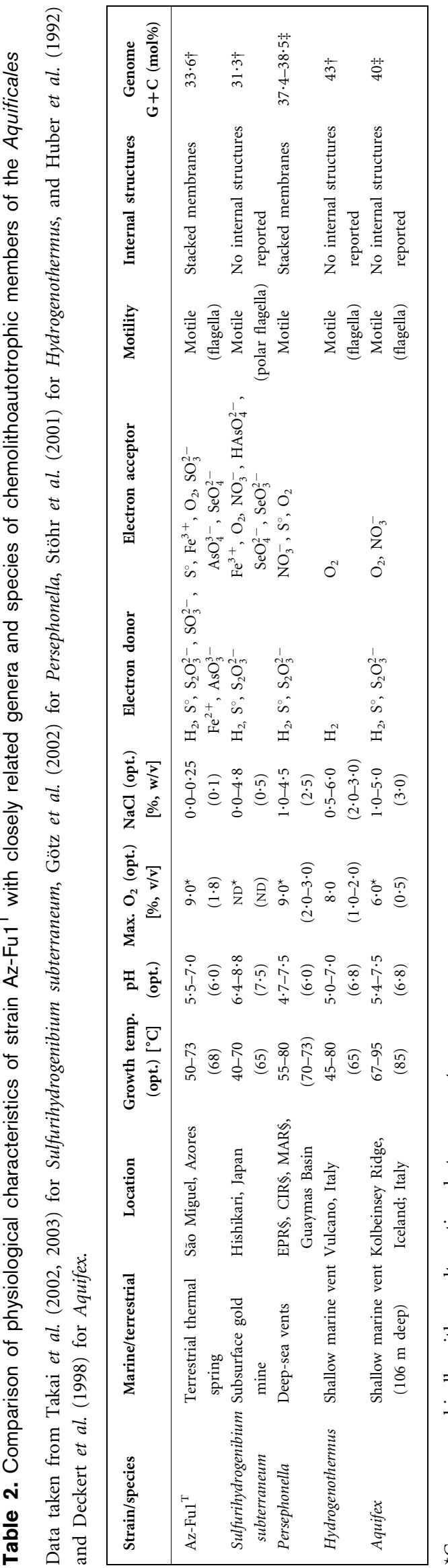


distant from the recently described lineages Persephonella marina and Hydrogenothermus marinus, respectively, and differs significantly from these lineages in their physiological growth requirements (Table 2). The $\mathrm{G}+\mathrm{C}$ content of the DNA of strain Az-Ful $1^{\mathrm{T}}$ is $33.6 \mathrm{~mol} \%$. Two mismatches were detected in the $16 \mathrm{~S}$ rRNA gene sequence which were confirmed to be real by RT-PCR and by cloning. These are located at Escherichia coli 16S rRNA positions 818 and 888. Furthermore, two 16S rRNA genes were detected in the Sulfurihydrogenibium strain Az-Fu1 $1^{\mathrm{T}}$ genome sequence (A.-L. Reysenbach \& J. F. Heidelberg, unpublished data).

The cells of $\mathrm{Az}-\mathrm{Fu} 1^{\mathrm{T}}$ strain are motile Gram-negative rods, varying from 0.9 to $2.0 \mu \mathrm{m}$ in length and from 0.4 to $0.5 \mu \mathrm{m}$ in width. Transmission electron microscopy of

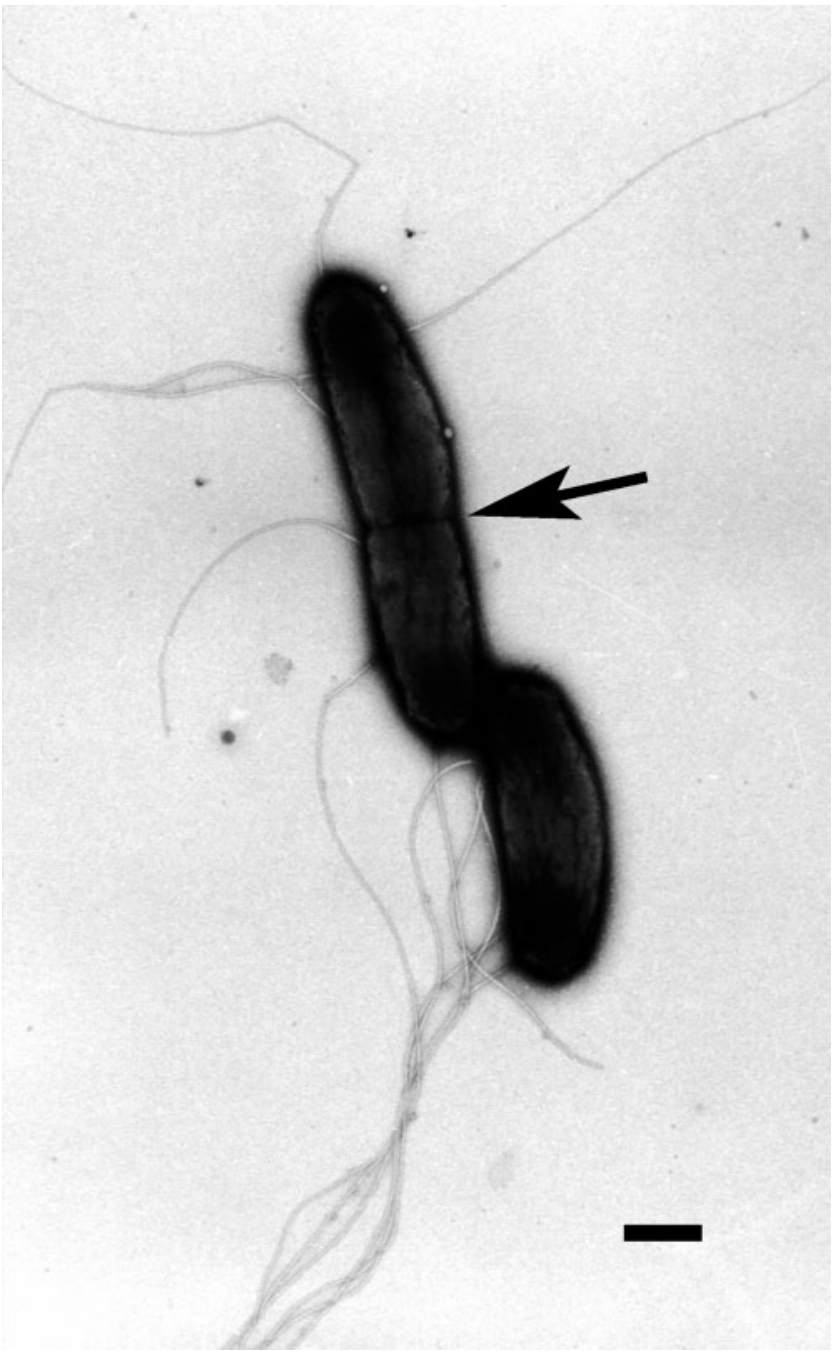

Fig. 1. Transmission electron micrograph of negatively stained Az-Fu1 ${ }^{\top}$ cells revealing flagella extending from the cell surface. Some flagella have been deformed during the process of staining so that their helicity has been lost. The longer cell is dividing and shows that cell division is by the typical Gram-negative constrictive process (arrow). Bar, $0.5 \mu \mathrm{m}$. negatively stained bacteria revealed flagella extending from the cell surface of many of the cells and constrictive division sites typical of actively growing cultures of Gram-negative rods (Fig. 1). The flagella were unsheathed and had a diameter of $\sim 15 \mathrm{~nm}$, which is typical for many bacteria (Wilson \& Beveridge, 1993). Endospores were not observed. Thin sections showed a typical Gram-negative cell envelope complete with outer and plasma membranes (Fig. 2) although, like Persephonella marina (Götz et al., 2002), it was difficult to differentiate the peptidoglycan layer as a distinct entity. When grown with $\mathrm{H}_{2}$ the cells tended to cluster, forming macrofilaments (clumps of filaments), even while agitated. Under iron-oxidizing and ironreducing conditions, $\mathrm{Az}-\mathrm{Fu} 1^{\mathrm{T}}$ cells were often found attached to minerals. Thin sections of samples grown under $\mathrm{H}_{2}$-oxidizing conditions, in the presence of $\mathrm{S}^{\circ}$, revealed unidentified structures that resembled internal stacked membranes with a particle periodicity on them (Fig. 3). Similar, but smaller membranous structures, have previously been reported for another member of the Aquificales, i.e. Persephonella (Götz et al., 2002). Such structures

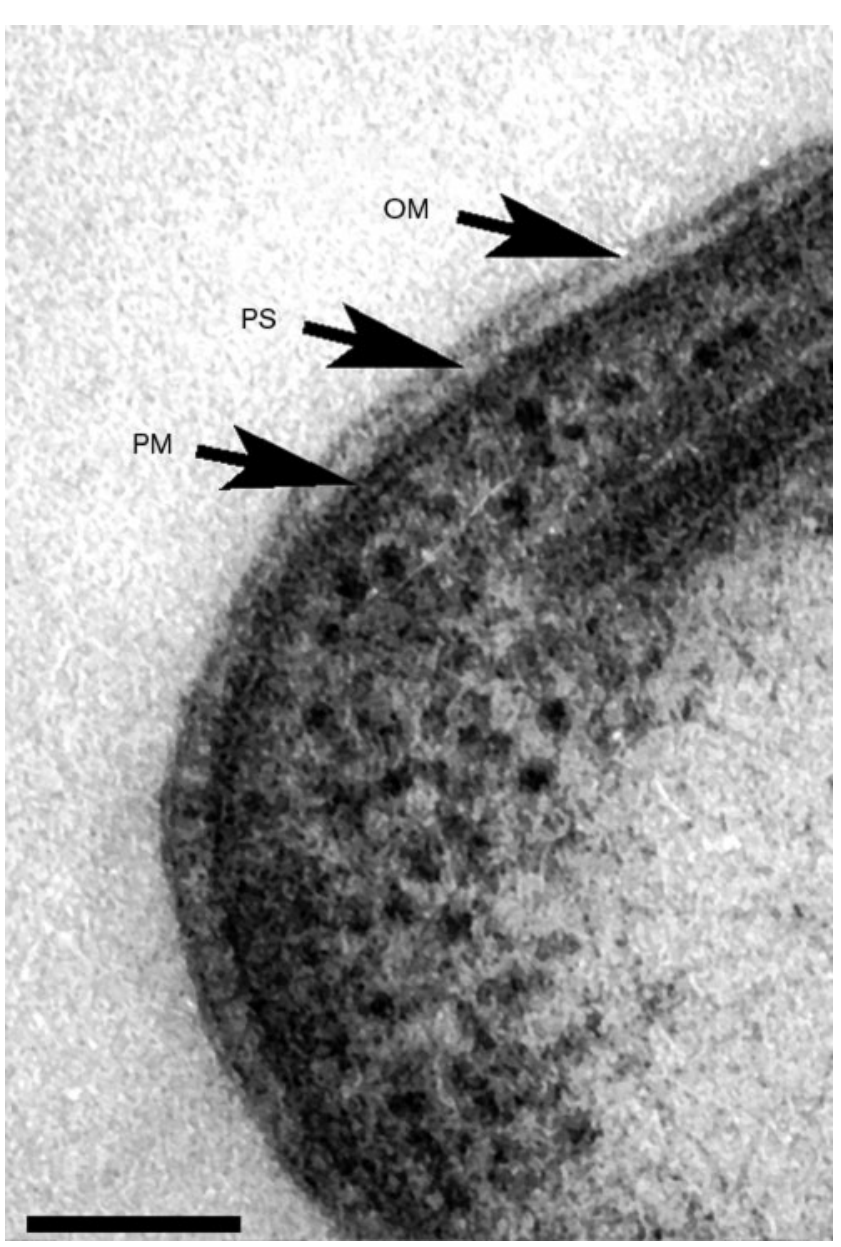

Fig. 2. Detail of the typical Gram-negative envelope of $A z-F u 1^{\top}$ shown in thin section. OM, outer membrane; PM, plasma membrane; PS, periplasmic space. Bar, $100 \mathrm{~nm}$. 


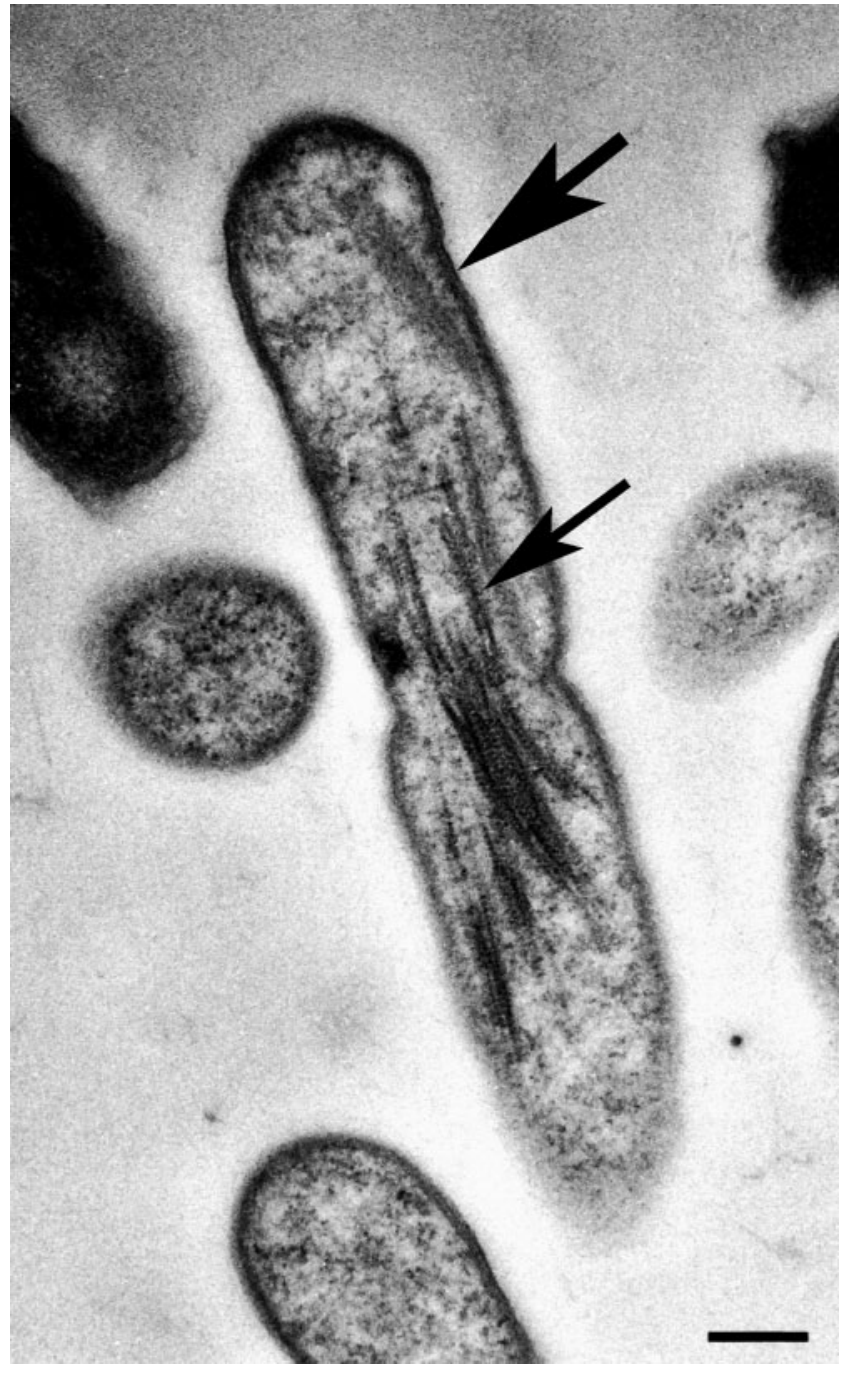

Fig. 3. Thin section of $\mathrm{Az}-\mathrm{Fu} 1^{\top}$ revealing the typical Gramnegative envelope (large arrow) as well as cytoplasmic structures that resemble stacked membranes (small arrow). Bar, $0.5 \mu \mathrm{m}$.

were not reported for Sulfurihydrogenibium subterraneum (Takai et al., 2002, 2003). Although internal membranes are often used to align enzymes for complex metabolic reactions, the function of these membranous structures is not yet known. Alternatively, these structures may resemble cytoplasmic axial filaments as have been reported for Escherichia coli (Okada et al., 1994); however, this is speculative without purification and extensive characterization of these structures.

Strain Az-Fu1 $1^{\mathrm{T}}$ grew from 50 to $73^{\circ} \mathrm{C}$ with optimal growth at $68{ }^{\circ} \mathrm{C}$ (doubling time about $2.5 \mathrm{~h}$ with no agitation). Growth occurred between $\mathrm{pH} 5 \cdot 5$ and $7 \cdot 0$ and was optimal at $\mathrm{pH}$ 6. Strain $\mathrm{Az}-\mathrm{Fu} 1^{\mathrm{T}}$ grew at salt concentrations from 0 to $0 \cdot 25 \%(\mathrm{w} / \mathrm{v}) \mathrm{NaCl}$, although growth rate was low at $0.25 \% \mathrm{NaCl}$. This physiological trait confirms that $\mathrm{Az}-\mathrm{Fu} 1^{\mathrm{T}}$ is the first freshwater isolate to be characterized within this phylogenetic lineage. Strain $\mathrm{Az}-\mathrm{Fu} 1^{\mathrm{T}}$ is a strict chemolithoautotroph and uses $\mathrm{CO}_{2}$ as sole carbon source. Furthermore, strain Az-Fu1 ${ }^{\mathrm{T}}$ does not use $\mathrm{NO}_{3}^{-}$as electron acceptor. Strain $\mathrm{Az}-\mathrm{Fu} 1^{\mathrm{T}}$ grew with up to $9 \cdot 0 \%$ oxygen, with optimal growth between 1.8 and $2 \cdot 0 \%(\mathrm{v} / \mathrm{v})$. There was no growth in the presence of $12 \cdot 0 \%(\mathrm{v} / \mathrm{v})$ oxygen. Growth under hydrogen-oxidizing conditions was enhanced by the presence of sulfur compounds $\left(\mathrm{S}^{\circ}, \mathrm{S}_{2} \mathrm{O}_{3}^{2-}\right.$ or $\left.\mathrm{SO}_{3}^{2-}\right)$ as reported for Hydrogenobacter (Bonjour \& Aragno, 1986). $\mathrm{Az}-\mathrm{Fu} 1^{\mathrm{T}}$ is able to use ferrous iron $\left(\mathrm{Fe}^{2+}\right)$ as electron donor in the presence of $\mathrm{O}_{2}$ or $\mathrm{S}^{\circ}$, and like Sulfurihydrogenibium subterraneum (Takai et al., 2002, 2003) ferric iron $\left(\mathrm{Fe}^{3+}\right)$ can be used as electron acceptor in the presence of $\mathrm{H}_{2}$ and $\mathrm{S}^{\circ}$. Sulfurihydrogenibium subterraneum was also tested for iron oxidation and, like $\mathrm{Az}-\mathrm{Fu} 1^{\mathrm{T}}$, it is capable of using ferrous iron $\left(\mathrm{Fe}^{2+}\right)$ as electron donor in the presence of $\mathrm{O}_{2}$.

\section{Comparison with related genera and species}

Together with Sulfurihydrogenibium subterraneum, Az-Fu1 ${ }^{\mathrm{T}}$ forms a distinct bacterial lineage within the Aquificales (Fig. 4), with a similar low $\mathrm{G}+\mathrm{C}$ content. Both strains share many characteristics with the rest of the Aquificales, such as microaerophilic growth. However, their distinct ability to use heavy metals and iron compounds as electron donors or acceptors (Tables 1 and 2) distinguish them from other members of the Aquificales.

There are several distinguishing features that set $\mathrm{Az}-\mathrm{Fu} 1^{\mathrm{T}}$ apart from Sulfurihydrogenibium subterraneum, such as salt tolerance and $\mathrm{pH}$ growth optima (Table 2). These differences may reflect their different habitats; $\mathrm{Az}-\mathrm{Fu}^{\mathrm{T}}$ has been obtained from terrestrial hot springs whereas Sulfurihydrogenibium subterraneum was obtained from a warm subterranean gold mine. Furthermore, unlike Sulfurihydrogenibium subterraneum, $\mathrm{Az}-\mathrm{Fu} 1^{\mathrm{T}}$ cannot grow aerobically, nor can it use nitrate as an electron acceptor. With the exception of Hydrogenothermus marinus and 'Aquifex aeolicus' (Table 2), all marine Aquificales isolates described to date are able to grow with $\mathrm{O}_{2}$ and $\mathrm{NO}_{3}^{-}$as electron acceptors and $\mathrm{H}_{2}$ as an electron donor, suggesting that perhaps Sulfurihydrogenibium subterraneum is more marine in origin. Furthermore, based on a conservative estimate and comparing only homologous nucleotides, $\mathrm{Az}-\mathrm{Fu} 1^{\mathrm{T}}$ is $2 \%$ different from Sulfurihydrogenibium subterraneum in the 16S rRNA sequence. Based on the phylogenetic position and distinct physiological characteristics of $\mathrm{Az}-\mathrm{Fu} \mathrm{l}^{\mathrm{T}}$, we propose that this isolate be named Sulfurihydrogenibium azorense.

\section{Description of Sulfurihydrogenibium azorense sp. nov.}

Sulfurihydrogenibium azorense (a.zo.ren'se. N. L. neut. adj. azorense from the Azores, the place of isolation).

Motile rods, $0 \cdot 4-0 \cdot 5 \times 0 \cdot 9-2 \cdot 0 \mu \mathrm{m}$. Cells can occur singly, in pairs or in filamentous clumps. Colonies are translucent. Grows best in the presence of sulfur compounds. 


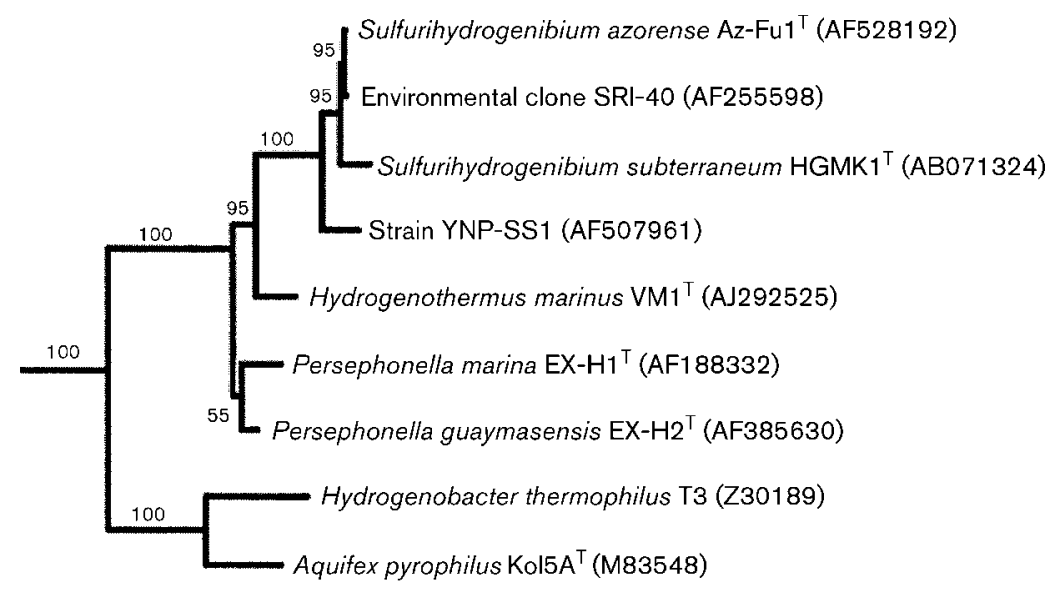

$0 \cdot 10$
Fig. 4. Maximum-likelihood phylogenetic tree showing the position of strain $\mathrm{Az}-\mathrm{Fu} 1^{\top}$. The scale bar represents the number of fixed mutations per nucleotide position. The numbers at the branch nodes are bootstrap values based on 100 bootstrap resamplings. The additional sequences used to generate the tree were Thermotoga maritima MSB- $8^{\top}$ (M21774), Thermosipho melanesiensis BI429 ${ }^{\top}$ (Z70248), Thermus thermophilus HB8 $^{\top}$ (X07998), Heliobacterium chlorum DSM $3682^{\top} \quad$ (M11212), Bacillus subtilis W168 (K00637), Escherichia coli (J01695) and Flexibacter flexilis DSM $6793^{\top}$ (M62794). 'Methanocaldococcus jannaschii' JAL-1 ${ }^{\top}$ (M59126) was used as the outgroup.
Optimal growth occurs at $68^{\circ} \mathrm{C}$ and growth occurs from 55 to $73^{\circ} \mathrm{C}$. The optimal pH for growth is $6 \cdot 0$, with a range from $5 \cdot 5$ to $7 \cdot 0$. Grows fastest with $0 \cdot 1 \%(\mathrm{w} / \mathrm{v}) \mathrm{NaCl}$; growth is inhibited with $\mathrm{NaCl}$ concentrations above $0 \cdot 25 \%$. Not capable of growth at $12 \%(\mathrm{v} / \mathrm{v}) \mathrm{O}_{2}$ final concentration. Doubling time of $2.5 \mathrm{~h}$ with $\mathrm{O}_{2}$ as electron acceptor and $\mathrm{H}_{2}$ as electron donor. Cells utilize $\mathrm{H}_{2}$, thiosulfate, $\mathrm{S}^{\circ}$ or $\mathrm{Fe}^{2+}$ as electron donors and $\mathrm{O}_{2}, \mathrm{~S}^{\circ}$ and $\mathrm{Fe}^{3+}$ as electron acceptors, but cannot use nitrate as electron acceptor. The $\mathrm{G}+\mathrm{C}$ content is $33.6 \mathrm{~mol} \%$. Isolated from a terrestrial hot spring $\left(68.4{ }^{\circ} \mathrm{C}, \mathrm{pH} 5.9\right)$ in the Água do Caldeirão area, Furnas, on São Miguel Island, Azores. The type strain is Az-Fu1 $1^{\mathrm{T}}\left(=\mathrm{DSM} \quad 15241^{\mathrm{T}}=\right.$ OCM $\left.825^{\mathrm{T}}\right)$. The GenBank accession number for the $16 \mathrm{~S}$ rRNA sequence of $\mathrm{Az}-\mathrm{Fu} 1^{\mathrm{T}}$ is AF528192.

\section{Acknowledgements}

The authors wish to thank Yitai Liu and Dorothee Götz for technical assistance in growth experiments, Amy Banta for assistance with phylogenetic analyses and Dianne Moyles for thin-section preparations. The help of David Boone and David Banta with naming this new isolate is greatly appreciated; although the name has changed since then, we liked your names better! This work was supported by NSF grants (OCE-9809136, OCE-0083134) to A.-L.R., an NSERC of Canada grant to T. J. B. and an FCT grant (Fundação para a Ciência e a Tecnologia, Ministério da Ciência, Portugal) BD (PRAXIS_XXI/BD/ 20010/99) to P. A. Electron microscopy was done at the NSERC Guelph Regional STEM Facility that is partially funded by an NSERC Major Facilities Access grant to T. J. B.

\section{References}

Aragno, M. (1992). Thermophilic, aerobic, hydrogen-oxidizing (knallgas) bacteria. In The Prokaryotes, vol. IV, 2nd edn, pp. 39173933. Edited by A. Balows, H. G. Trüper, M. Dworkin, W. Harder \& K.-H. Schleifer. New York: Springer.

Beffa, T., Blanc, M. \& Aragno, M. (1996). Obligately and facultatively autotrophic, sulphur- and hydrogen-oxidizing thermophilic bacteria isolated from hot composts. Arch Microbiol 165, 34-40.
Beveridge, T. J., Popkin, T. J. \& Cole, R. C. (1994). Electron microscopy. In Methods for General and Molecular Bacteriology, pp. 42-71. Edited by P. Gerhardt. Washington, DC: American Society for Microbiology.

Bonjour, F. \& Aragno, M. (1986). Growth of thermophilic, obligatorily chemolithoautotrophic hydrogen-oxidizing bacteria related to Hydrogenobacter with thiosulfate and elemental sulfur as electron and energy source. FEMS Microbiol Lett 35, 11-15.

Boone, D. R., Johnson, R. L. \& Liu, Y. (1989). Diffusion of the interspecies electron carriers $\mathrm{H}_{2}$ and formate in methanogenic ecosystems and its implication in the measurement of $K_{\mathrm{m}}$ for $\mathrm{H}_{2}$ or formate uptake. Appl Environ Microbiol 55, 1735-1741.

Burggraf, S., Olsen, G. J., Stetter, K. O. \& Woese, C. R. (1992). A phylogenetic analysis of Aquifex pyrophilus. Syst Appl Microbiol 15, 352-356.

Cashion, P., Holder-Franklin, M. A., McCully, J. \& Franklin, M. (1977). A rapid method for the base ratio determination of bacterial DNA. Anal Biochem 81, 461-466.

Deckert, G., Warren, P. V., Gaasterland, T. \& 12 other authors (1998). The complete genome of the hyperthermophilic bacterium Aquifex aeolicus. Nature 392, 353-358.

Eder, W. \& Huber, R. (2002). New isolates and physiological properties of the Aquificales and description of Thermocrinis albus sp. nov. Extremophiles 6, 309-318.

Ferguson, T. J. \& Mah, R. A. (1983). Isolation and characterization of an $\mathrm{H}_{2}$-oxidizing methanogen. Appl Environ Microbiol 45, 265-274.

Götz, D., Banta, A., Beveridge, T. J., Rushdi, A. I., Simoneit, B. R. T. \& Reysenbach, A.-L. (2002). Persephonella marina gen. nov., sp. nov. and Persephonella guaymasensis sp. nov., two novel thermophilic hydrogen-oxidizing microaerophiles from deep-sea hydrothermal vents. Int J Syst Evol Microbiol 52, 1349-1359.

Hjörleifsdottir, S., Skirnisdottir, S., Hreggvidsson, G. O., Holst, O. \& Kristjansson, J. K. (2001). Species composition of cultivated and noncultivated bacteria from short filaments in an Icelandic hot spring at $88^{\circ} \mathrm{C}$. Microb Ecol 42, 117-125.

Huber, R., Wilharm, T., Huber, D. \& 7 other authors (1992). Aquifex pyrophilus gen. nov. sp. nov., represents a novel group of marine hyperthermophilic hydrogen-oxidizing bacteria. Syst Appl Microbiol 15, 340-351.

Huber, R., Eder, W., Heldwein, S., Wanner, G., Huber, H., Rachel, R. \& Stetter, K. O. (1998). Thermocrinis ruber gen. nov., sp. nov., a 
pink-filament-forming hyperthermophilic bacterium isolated from Yellowstone National Park. Appl Environ Microbiol 64, 3576-3583.

Jones, T. G., Gardener, S. \& Simon, B. M. (1983). Bacterial reduction of ferric iron in a stratified eutrophic lake. J Gen Microbiol 129, 131-139.

Jukes, T. H. \& Cantor, C. R. (1969). Evolution of protein molecules. In Mammalian Protein Metabolism, pp. 21-132. Edited by H. N. Munro. New York: Academic Press.

Kawasumi, T., Igarashi, Y., Kodama, T. \& Minoda, Y. (1984). Hydrogenobacter thermophilus gen. nov., sp. nov., an extremely thermophilic, aerobic, hydrogen-oxidizing bacterium. Int J Syst Bacteriol 34, 5-10.

Kristjansson, J. K., Ingason, A. \& Alfredsson, G. A. (1985). Isolation of thermophilic obligately autotrophic hydrogen-oxidizing bacteria, similar to Hydrogenobacter thermophilus from Icelandic hot springs. Arch Microbiol 140, 321-325.

Kryukov, V. R., Saveleva, N. D. \& Pusheva, M. A. (1983). Calderobacterium hydrogenophilum, nov. gen., nov. sp., an extremely thermophilic hydrogen bacterium and its hydrogenase activity. Mikrobiologiya 52, 781-788 (in Russian).

Masaharu, I., Yasuo, I. \& Tohru, K. (1987). Colony formation of Hydrogenobacter thermophilus on a plate solidified with gelrite. Agric Biol Chem 51, 3139-3141.

Mesbah, M., Premachandran, U. \& Whitman, W. (1989). Precise measurement of the $\mathrm{G}+\mathrm{C}$ content of deoxyribonucleic acid by high performance liquid chromatography. Int J Syst Bacteriol 39, 159-167.

Nishihara, H., Igarashi, Y. \& Kodama, T. (1990). A new isolate of Hydrogenobacter, an obligately chemolithotrophic, thermophilic, halophilic and aerobic hydrogen-oxidizing bacterium from seaside saline hot spring. Arch Microbiol 153, 294-298.

Okada, Y., Wachi, M., Hirata, A., Suzuki, K., Nagai, K. \& Matsuhashi, M. (1994). Cytoplasmic axial filaments in Escherichia coli cells: possible function in the mechanism of chromosome segregation and cell division. J Bacteriol 176, 917-922.

Pitulle, C., Yang, Y., Marchiani, M., Moore, E. R. B., Siefert, J. L., Aragno, M., Jurtshuk, P. \& Fox, G. E. (1994). Phylogenetic position of the genus Hydrogenobacter. Int J Syst Bacteriol 44, 620-626.

Ratkowsky, D. A., Olley, J., McMeekin, T. A. \& Ball, A. (1982). Relationship between temperature and growth rate of bacterial cultures. J Bacteriol 149, 1-5.

Reysenbach, A.-L., Banta, A., Boone, D. R., Cary, S. C. \& Luther, G. W. (2000a). Microbial essentials at hydrothermal vents. Nature 404, 835-836.

Reysenbach, A.-L., Ehringer, M. \& Hershberger, K. (2000b). Microbial diversity at $83^{\circ} \mathrm{C}$ in Calcite Springs, Yellowstone
National Park: another environment where Aquificales and 'Korarchaeota' coexist. Extremophiles 4, 61-67.

Reysenbach, A.-L., Götz, D. \& Yernool, D. (2002a). Microbial diversity of marine and terrestrial thermal springs. In Biodiversity of Microbial Life, pp. 394-396. Edited by J. T. Staley \& A.-L. Reysenbach. New York: Wiley-Liss.

Reysenbach, A.-L., Götz, D., Banta, A., Jeanthon, C. \& Fouquet, I. (2002b). Expanding the distribution of the Aquificales to the deepsea vents on Mid-Atlantic Ridge and Central Indian Ridge. Cah Biol Mar 43, 425-428.

Saveleva, N. D., Kryukov, V. R. \& Pusheva, M. A. (1982). An obligate thermophilic hydrogen bacterium. Mikrobiologiya 51, 765-769 (in Russian).

Shima, S. \& Suzuki, K. I. (1993). Hydrogenobacter acidophilus sp. nov., a thermoacidophilic, aerobic, hydrogen-oxidizing bacterium requiring elemental sulfur for growth. Int J Syst Bacteriol 43, 703-708.

Skirnisdottir, S., Hreggvidsson, G. O., Hjörleifsdottir, S., Marteinsson, V. T., Petursdottir, S. K., Holst, O. \& Kristjansson, J. (2000). Influence of sulfide and temperature on species composition and community structure of hot spring microbial mats. Appl Environ Microbiol 66, 2835-2841.

Stöhr, R., Waberski, A., Völker, H., Tindall, B. J. \& Thomm, M. (2001). Hydrogenothermus marinus gen. nov., sp. nov., a novel thermophilic hydrogen-oxidizing bacterium, recognition of Calderobacterium hydrogenophilum as a member of the genus Hydrogenobacter and proposal of the reclassification of Hydrogenobacter acidophilus as Hydrogenobaculum acidophilum gen. nov., comb. nov., in the phylum 'Hydrogenobacter/Aquifex'. Int J Syst Evol Microbiol 51, 1853-1862.

Takai, K., Hirayama, H., Sakihama, Y., Inagaki, F., Yamato, Y. \& Horikoshi, K. (2002). Isolation and metabolic characteristics of previously uncultured members of the order Aquificales in a subsurface gold mine. Appl Environ Microbiol 68, 3046-3054.

Takai, K., Kobayashi, H., Nealson, K. H. \& Horikoshi, K. (2003). Sulfurihydrogenibium subterraneum gen. nov., sp. nov., from a subsurface hot aquifer. Int J Syst Evol Microbiol 53, 823-827.

Tamaoka, J. \& Komagata, K. (1984). Determination of DNA base composition by reversed-phase high-performance liquid chromatography. FEMS Microbiol Lett 25, 125-128.

Wilson, D. R. \& Beveridge, T. J. (1993). Bacterial flagellar filaments and their component flagellins. Can J Microbiol 39, 451-472.

Yamamoto, H., Hiraishi, A., Kato, K., Chiura, H. X., Maki, Y. \& Shimuzu, A. (1998). Phylogenetic evidence for the existence of novel thermophilic bacteria in hot springs sulfur-turf microbial mats in Japan. Appl Environ Microbiol 64, 1680-1687. 